Disclosure of Interests: lain Mclnnes Consultant of: AbbVie, AstraZeneca, Boehringer Ingelheim, Bristol Myers, Celgene, Janssen, Leo, Lilly, Novartis, Pfizer, and UCB, Grant/research support from: AbbVie, AstraZeneca, Boehringer Ingelheim, Bristol Myers, Celgene, Janssen, Leo, Lilly, Novartis, Pfizer, and UCB, William Tillett Speakers bureau: AbbVie, Amgen, Celgene, Janssen, Lilly, MSD, Novartis, Pfizer, and UCB, Consultant of: AbbVie, Amgen, Celgene, Janssen, Lilly, MSD, Novartis, Pfizer, and UCB, Philip J Mease Speakers bureau: AbbVie, Amgen, Boehringer Ingelheim, Bristol Myers, Celgene, Galapagos, Genentech, Gilead, GlaxoSmithKline, Janssen, Leo, Lilly, Merck, Novartis, Pfizer, Sun Pharma, and UCB, Consultant of: AbbVie, Amgen, Boehringer Ingelheim, Bristol Myers, Celgene, Galapagos, Genentech, Gilead, GlaxoSmithKline, Janssen, Leo, Lilly, Merck, Novartis, Pfizer, Sun Pharma, and UCB, Grant/research support from: AbbVie, Amgen, Boehringer Ingelheim, Bristol Myers, Celgene, Galapagos, Genentech, Gilead, GlaxoSmithKline, Janssen, Leo, Lilly, Merck, Novartis, Pfizer, Sun Pharma, and UCB, Kurt de Vlam Speakers bureau: Celgene Eli Lilly, Galapagos, Novartis, and UCB, Consultant of: Celgene, Eli Lilly, Galapagos, Novartis, and UCB, Grant/ research support from: Celgene and Galapagos, Louis Bessette Speakers bureau: Amgen, BMS, Janssen, UCB, AbbVie, Pfizer, Merck, Celgene, Lilly, Novartis, and Sanofi, Consultant of: Amgen, BMS, Janssen, UCB, AbbVie, Pfizer, Merck, Celgene, Lilly, Novartis, Sanofi, Gilead, Grant/research support from: Amgen, BMS, Janssen, UCB, AbbVie, Pfizer, Merck, Celgene, Lilly, Novartis, Sanofi, and Gilead, Ralph Lippe Shareholder of: AbbVie, Employee of: AbbVie, anna maniccia Shareholder of: AbbVie, Employee of: AbbVie, Patrick Zueger Shareholder of: AbbVie, Employee of: AbbVie, Dai Feng Shareholder of: AbbVie, Employee of: AbbVie, Koji Kato Shareholder of: AbbVie, Employee of: AbbVie, Andrew Ostor Consultant of: AbbVie, BMS, Roche, Janssen, Lilly, Novartis, Pfizer, UCB, Gilead, and Paradigm. DOI: 10.1136/annrheumdis-2021-eular.1633

\section{POS1048 IN PHASE-3 TRIALS DISCOVER 1 \& 2, GUSELKUMAB REDUCED FATIGUE OVER 52 WEEKS IN PATIENTS WITH PSORIATIC ARTHRITIS AND DEMONSTRATED INDEPENDENT TREATMENT EFFECTS ON FATIGUE AFTER ADJUSTMENT FOR CLINICAL RESPONSE (ACR20)}

P. Rahman ${ }^{1}$, P. Helliwell ${ }^{2}$, A. Deodhar ${ }^{3}$, A. Kollmeier ${ }^{4}$, E. C. Hsia ${ }^{4,5}$, B. Zhou ${ }^{6}$, X. Lin ${ }^{7}$, C. Han $^{8}$, P. J. Mease ${ }^{9} .{ }^{1}$ Memorial University of Newfoundland, Disicpline of Medicine, Faculty of Medicine, St. Johns, Canada; ${ }^{2}$ University of Leeds, Clinical Rheumatology, Leeds, United Kingdom; ${ }^{3}$ Oregon Health \& Science University, Division of Arthritis \& Rheumatic Diseases, Oregon, United States of America; ${ }^{4}$ Janssen Research \& Development, LJ IMMUNOLOGY, Spring House, United States of America; ${ }^{5}$ University of Pennsylvania School of Medicine, Division of Rheumatology, Philadelphia, United States of America; ${ }^{6}$ Janssen Research \& Development, CLINICAL BIOSTATS PA, Spring House, United States of America; ${ }^{7}$ Janssen Research \& Development, SMM-PA, Spring House, United States of America; ${ }^{8}$ Janssen Research \& Development, STRATEGIC MKT ACCESS, Spring House, United States of America; ${ }^{9}$ Swedish Medical Center/Providence St Joseph Health and University of Washington School of Medicine, Department of Internal Medicine, Seatle, United States of America

Background: DISCOVER 1 \& 2 are phase-3 trials of guselkumab (GUS, an IL-23 inhibitor) in patients with psoriatic arthritis (PsA). In both trials, treatment with GUS led to significantly more improvement than placebo (PBO) in the primary endpoint (American College of Rheumatology 20\% improvement criteria [ACR20]) and in other measures of arthritis and psoriasis at week (w) $24^{1,2}$ and these improvements were maintained through 1 year of active treatment. ${ }^{3,4}$ Objectives: To evaluate the effect of GUS on fatigue in DISCOVER 1 \& 2 using the patient reported outcome (PRO) FACIT-Fatigue, which has demonstrated content validity and strong psychometric properties in clinical trials. ${ }^{5}$

Methods: DISCOVER 1 \& 2 enrolled patients with active PsA, despite non-biologic DMARDS or NSAIDS, who were biologic naïve except $~ 30 \%$ of patients in DISCOVER 1 who had received 1-2 TNFi. Patients were randomized (1:1:1) in a blinded fashion to subcutaneous GUS $100 \mathrm{mg}$ at w0, w4, then every (q) 8w; GUS $100 \mathrm{mg} \mathrm{q4w}$; or matching PBO. At w24, PBO patients were switched to GUS q4w. Concomitant treatment with select non-biologic DMARDS, oral corticosteroids, and NSAIDs was allowed. The FACIT-Fatigue is a 13-item PRO assessing fatigue and its impact on daily activities and function over the past 7 days, total score ranging from 0 to 52 , higher score denoting less fatigue. A change of $\geq 4$ points is considered clinically meaningful. ${ }^{5}$ The change from baseline in FACIT-Fatigue presented below is based on observed data. Mediation analysis ${ }^{6}$ was applied to the treatment effect of GUS on FACIT-Fatigue to estimate the natural direct and indirect effects, after adjusting for ACR20 response (Table 1).

Results: At baseline in DISCOVER 1 \& 2, the mean FACIT-fatigue scores (SD) were 30.4 (10.4) and 29.7 (9.7), respectively, indicating that patients with PsA experienced fatigue worse than the general population. At w24 in the DISCOVER trials, treatment with GUS led to significant improvements in FACIT-Fatigue scores compared with PBO, as early as w16 in DISCOVER 1 and w8 in DISCOVER 2. Improvements in fatigue were similar between GUS $q 4 w$ and $q 8 w$ doses, and the improvements at w24 were maintained through w52 (Figure 1). After a switch to GUS q4w at w24, PBO patients achieved FACIT-Fatigue scores that were comparable to those of GUS patients (Figure 1). $54 \%-63 \%$ of GUS patients compared with $35 \%-46 \%$ of PBO patients achieved clinically meaningful improvement ( $\geq 4$ points) in FACIT-Fatigue at w24 (P $\leq 0.003$ ). At w52, 61\%-70\% of both GUS and PBO to GUS groups reached this improvement. As evaluated by mediation analysis at w24, GUS had independent positive treatment effects on fatigue (12\%-36\% in the q8w GUS dosing group and $69 \%-70 \%$ in the q4w GUS group) after adjustment for ACR20 response (Table 1).

Conclusion: In 2 phase-3 trials, GUS treatment improved fatigue when compared to PBO during PBO-controlled periods and maintained improvements through 1 year of active treatment. Substantial proportions of those effects were independent of the effects on ACR20, especially for the q4W dosing group.

\section{REFERENCES:}

[1] Deodhar et al. Lancet 2020;395:1115

[2] Mease et al. Lancet 2020;395:1126

[3] Ritchlin et al. EULAR20. SAT0397

[4] Mclnnes et al. EULAR2O. SAT0402

[5] Cella et al. J Patient-Reported Outcomes 2019;3:30

[6] Valeri et al. Psychologic Meth 2013;18:137

Table 1. Mediation Analysis: Guselkumab Has Direct Effects and Indirect Effects (Mediated through ACR20) on Fatigue in PsA

\begin{tabular}{|c|c|c|c|}
\hline & Effect & $\begin{array}{l}\text { GUS } 100 \mathrm{mg} \text { q8w vs. } \\
\text { PBO }(95 \% \mathrm{Cl})\end{array}$ & $\begin{array}{l}\text { GUS } 100 \mathrm{mg} \mathrm{q} 4 \mathrm{w} \\
\text { vs. PBO }(95 \% \mathrm{Cl})\end{array}$ \\
\hline \multirow[t]{4}{*}{ DISCOVER-1 } & Total Effect & $3.1(1.0,5.2)$ & $3.8(1.9,5.4)$ \\
\hline & & $(p<0.02)$ & $(p<0.02)$ \\
\hline & $\%$ Direct Effect & $11.7 \%$ & $68.5 \%$ \\
\hline & $\begin{array}{l}\% \text { Indirect effect mediated } \\
\text { by ACR20 }\end{array}$ & $88.3 \%$ & $31.5 \%$ \\
\hline \multirow[t]{4}{*}{ DISCOVER-2 } & Total Effect & $4.0(2.4,5.5)$ & $3.6(2.1,5.0)$ \\
\hline & & $(p<0.02)$ & $(p<0.02)$ \\
\hline & $\%$ Direct Effect & $36.3 \%$ & $69.7 \%$ \\
\hline & $\begin{array}{l}\% \text { Indirect effect mediated } \\
\text { by ACR20 }\end{array}$ & $63.7 \%$ & $30.3 \%$ \\
\hline
\end{tabular}

ACR, American College of Rheumatology; CI, confidence interval; GUS, guselkumab; PBO placebo; PsA, psoriatic arthritis; q4W, every 4 weeks; q8W, every 8 weeks

Disclosure of Interests: Proton Rahman Speakers bureau: Received speakers fees from Abbott, AbbVie, Amgen, BMS, Celgene, Lilly, Janssen, Novartis, Pfizer, Grant/research support from: Received grant/research support from Janssen and Novartis, consultation fees from Abbott, AbbVie, Amgen, BMS, Celgene, Lilly, Janssen, Novartis, and Pfizer, Philip Helliwell Consultant of: Consultation fees paid to charity (AbbVie, Amgen, Pfizer, UCB) or himself (Celgene, Galapagos), Grant/research support from: Received grants/research support paid to charity (AbbVie, Janssen, Novartis), Atul Deodhar Speakers bureau: Received speakers fees from AbbVie, Amgen, Boehringer Ingelheim, Bristol Myer Squibb (BMS), Eli Lilly, GSK, Janssen, Novartis, Pfizer, UCB, Consultant of: Received consultation fees from AbbVie, Amgen, Boehringer Ingelheim, Bristol Myer Squibb (BMS), Eli Lilly, GSK, Janssen, Novartis, Pfizer, UCB, Grant/research support from: Received grant/research support from AbbVie, Eli Lilly, GSK Novartis, Pfizer, UCB, Alexa Kollmeier Shareholder of: Shareholder of Johnson \& Johnson, Employee of: Employee of Janssen Research \& Development, LLC, Elizabeth C Hsia Shareholder of: Shareholder of Johnson \& Johnson, Employee of: Employee of Janssen Research \& Development, LLC, Bei Zhou Shareholder of: Shareholder of Johnson \& Johnson, Employee of: Employee of Janssen Research \& Development, LLC, Xiwu Lin Shareholder of: Shareholder of Johnson \& Johnson, Employee of: Employee of Janssen Research \& Development, LLC, Chenglong Han Shareholder of: Shareholder of Johnson \& Johnson, Employee of: Employee of Janssen Research \& Development, LLC, Philip $\mathrm{J}$ Mease Speakers bureau: Received speakers fees from Abbott, Amgen, Biogen Idec, BMS, Eli Lilly, Genentech, Janssen, Pfizer, UCB, Consultant of: Received consultation fees from Abbott, Amgen, Biogen Idec, BMS, Celgene Corporation, Eli Lilly, Novartis, Pfizer, Sun Pharmaceutical, UCB, Grant/research support from: Received grant/research support from Abbott, Amgen, Biogen Idec, BMS, Celgene Corporation, Eli Lilly, Novartis, Pfizer, Sun Pharmaceutical, UCB. DOI: 10.1136/annrheumdis-2021-eular.1686

\section{POS1049 EFFECT OF FILGOTINIB ON PASDAS: DRIVERS OF LOW AND VERY LOW ACTIVITY UP TO WEEK 100}

L. C. Coates $^{1}$, P. J. Mease ${ }^{2,3}$, P. Helliwell ${ }^{4}$, F. Van den Bosch ${ }^{5}$, M. Trivedi ${ }^{6}$, M. Alani ${ }^{6,7}$, F. O. Le Brun ${ }^{8}$, R. Besuyen ${ }^{9}$, L. Gheyle ${ }^{10}$, E. Gvozdenovic ${ }^{11}$, D. D. Gladman ${ }^{12} .{ }^{1}$ University of Oxford, Nuffield Department of Orthopaedics, Rheumatology and Musculoskeletal Sciences, Oxford, United Kingdom; 